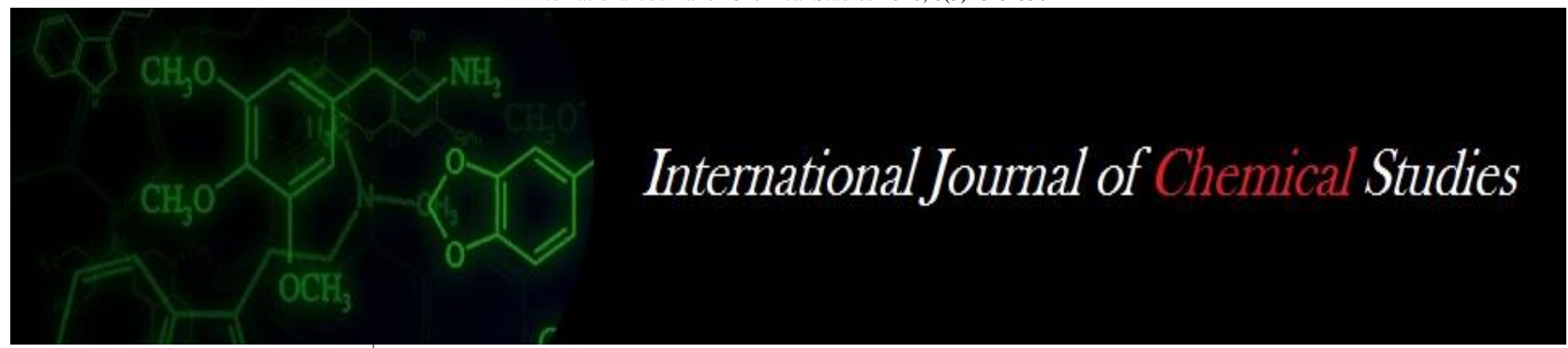

P-ISSN: 2349-8528

E-ISSN: 2321-4902

www.chemijournal.com

IJCS 2020; 8(5): 845-850

(C) 2020 IJCS

Received: 05-06-2020

Accepted: 15-07-2020

Yashmin Nongrum

Department of Food Science and

Nutrition, College of Community

Science, Assam Agricultural

University, Jorhat, Assam, India

Mansi Tiwari

Department of Food Science and

Nutrition, College of Community

Science, Assam Agricultural

University, Jorhat, Assam, India

\section{Possible role of Immunonutrients in combating Covid-19 outbreak}

\section{Yashmin Nongrum and Mansi Tiwari}

\section{DOI: https://doi.org/10.22271/chemi.2020.v8.i51.10404}

\begin{abstract}
With the emergence of Covid-19 in the late December 2019, the world has seen tremendous fatalities. Numbers of patients affected with corona viruses are increasing with every passing day. A number of vaccine are under development by several government and private agencies, however no such vaccines have been developed completely till date. The only possible solution at present time is to have a stronger immunity which could be attained with proper nutrition. Several nutrients such as vitamin C, vitamin D, Vitamin A, zinc, Selenium and other macronutrients are known to have potential impact on modulating immune responses. Therefore an attempt was made to review the possible role of immune-nutrients in combating with respiratory symptoms associated with covid-19.
\end{abstract}

Keywords: Immuno-nutrients, covid-19, SARS-CoV, Coronavirus

\section{Introduction}

Coronaviruses are a class of pathogens that infects animals and humans. On March 2020, WHO recognized Covid-19 which is a disease caused by severe acute respiratory syndrome coronavirus 2 (SARS-Cov-2) as a global pandemic ${ }^{[1]}$, whose outbreak was first identified in Wuhan, China, in late December $2019^{[2]}$. The two large scale pandemics caused by coronavirus in the past decades were SARS and Middle east syndrome ${ }^{[3]}$. SARS-Cov thought to be found in bats thereby causing a future outbreak from animal to human transmission [3] which initially started from the local sea food market that had infected 2761 people in China thereby leading to 80 deaths and infection of 33 people in 10 additional countries as of January 2020. As per the Worldometer report Coronavirus Cases increased to $26.795,847$, deaths 878,963 and recovered 518,907,692 ${ }^{[4]}$. Active cases in India as per Ministry of Health \& Family Welfare as of $5^{\text {th }}$ September 2020 is 4.02 million ${ }^{[5]}$.

The symptoms associated with Covid 19 are fever, dry cough, Breathing difficulties, headache, bodyache, loss of taste and smell. The onset of disease may lead to progressive respiratory failure owing to alveolar damage ${ }^{[6]}$. Clinicians determine the disease as to be caused by the virus induced pneumonia according to the symptoms observed as rise in body temperature, decrease in lymphocytes and WBC count. However as the present situation is concerned, the number of vaccines are under development by government agencies and many of which are undergoing clinical trials. But until the time vaccines or specific medications are developed to fight the lethal effects of Covid 19, our immune system could play a important role to cope up with the stress caused by the virus.

\section{Focus on Immunity}

The immune system comprises of innate immune response and adaptive immune response. In simpler terms, we could describe the innate works as the first response or already built immunity that is always on (skin, mucosa, gastric juice, epithelial cells) and immediate response (neutrophils, antigen presenting cells). It is less effective than adaptive immunity. Innate immunity can be poor in person with poor immune function for example undernourished children found to have a poor range of innate immune responses ${ }^{\text {[7] }}$. Another respondent of immune response is adaptive immunity that is specific to the pathogen. This are largely driven by $\mathrm{T}$ cells. $\mathrm{T}$ cells activate $\mathrm{B}$ cells to produce antibody. $\mathrm{T}$ cells have several categories and memory for life, example if they are exposed to specific organism since the organism doesn't change its genetic make up it will be recognised till then.

\section{Mansi Tiwar}

Department of Food Science and Nutrition, College of Community Science, Assam Agricultural University, Jorhat, Assam, India 
They produce pro inflammatory Cytokines example interleukins like IL2 which are antiviral. Treg cells that produce IL10 which maintain immune tolerance and avoid damage to self antigens and stop the immune response at the right moment. B cells produce immunoglobulins which is used for diagnosis.

Since a well functioning immune system could be a key to provide defense mechanism against pathogens such as viruses, bacteria, fungi that exist in the environment thereby providing an exclusion barrier, identifying and eliminating the infective agents. Good immune function may not prevent but the virus could be eliminated with initial effect example in younger people. It have been observed that higher risk of death seem to be associated with elderly age $>60$ years due to immunosenecence and also in people with metabolic syndrome as such obesity, diseases as such diabetes, hypertension, cardiovascular disease, chronic lung disease independent of age. Undernourished population are found to be more associated with upper respiratory tract infections clearly associated with immunity since innate immunity is affected in undernourished population. Several studies have shown that hypoalbumenic whose serum albumin levels are low, lymphopenia that is having low lymphocyte count, low pre albumin which is a bio marker of under nutrition ${ }^{[8]}$ are found to have more complications associated with Covid 19 due to decline in immune response because of undernutrition. So for the viral clearance and infection recovery, the activation of host immune response is needed sine the immune system is functioning at all times and also acquired immunity become active in presence of pathogen which demands the need of nutrients to provide the real source of energy. This source could be exogenous(from diet) and endogenous. Thus Immunonutrition could be a means to achieve this since innate and acquired immunity -the two functional divisions immune system and be supported by Human nutrition. and as we all know nutrition is a key determinant of health ${ }^{[9]}$. Therefore the present review paper extrapolates how immunonutrients could play a major role or prehabilitation to cope up with lethal virus called Covid-19.

\section{Nutrition and Immune function}

Though there is no specific evidence that nutritional measures can protect from or cure Covid 19, there is hope-innate and acquired immune function may be supported by human nutrition as it can surely work as a prehabilitation to prepare our immune system thereby making it strong to fight the virus and lessen the further complications or effects due to Covid 19 infection. It has been observed deficiencies in essential immunonutrients can have negative impact on the immune system thereby decreasing the power of resistance to infection. The nutrients that granted impact in the health contributing to the normal functioning of immune system are Vitamin C, Vitamin D, zinc, Selenium, Vitamin A, Vitamin E ${ }^{[10]}$. Other nutrients as such omega-3, vitamin $\mathrm{B}_{6}$, niotinamide, non essential amino acids as such arginine and glutamine (cellular energy source) also plays a major role in supporting effective immune system by helping to resolve the inflammatory response ${ }^{[10]}$.

With respect to innate immunity, the nutrients listed above would collectively function to support the development and maintenance of physical barriers, production and activity of antimicrobial proteins, growth, differentiation and mortility/ chemotaxis of innate cells, phagocytic and killing (oxidative burst) activities of neutrophils and macrophages and promotion of and recovery from inflammation. They also support adaptive immunity via lymphocyte differentiation, proliferation, antibody production and the generation of memory cells. Keeping this points in view, different studies have been reviewed to elucidate the role of immunonutrients in combating against respiratory diseases and for possible treatment of its symptoms as such cough, fever, breathelessness etc. which is also seen in patients suffering from Covid 19.

Vitamin A: It is a fat soluble, unsaturated monohydric alcohol containing an alicyclic ring ${ }^{[11]}$. The active form of vitamin A exits as retinol, retinal and retinoic acid among which highest biological activity is shown by retinoic acid ${ }^{[12]}$. The primary function of vitamin A includes maintenance of proper vision, growth and integrity of epithelial tissue and cells [13]. Further, several studies have also found the immunological role of Vitamin A ${ }^{[14-17]}$. Since 1920's vitamin A has been known to have anti-infective infective properties and so are also called "anti-infective vitamin" ${ }^{[18]}$. Several clinical trials and appropriately designed experiments have demonstrated the efficacy of vitamin A in preventing the detrimental health hazards associated to several classes of virus. In a randomized clinical trials conducted by Long et al., $2007^{[19]}$ on a divergent effects of vitamin A supplementation on specific outcomes of NoV infection it was seen that vitamin A supplementation has divergent effects on NoVassociated outcomes, with supplementation reducing the rate of NoV GII infection. Vitamin A deficiencies are also associated to several respiratory tracts infections. Earlier investigations Sommer et al. $2003^{[20]}$ showed that vitamin A status is more strongly linked to the risk of respiratory disease and diarrhoea than to the overall nutritional status. Vitamin A supplementation has also proved to be effective for individuals at high risk at high risk of tuberculosis ${ }^{[21]}$. Several observational studies reported the association of vitamin A deficiency with higher risk of asthma and severe wheezing [22${ }^{25]}$. Jeet et al. $2013^{[26]}$ reported low vitamin A diets might compromise the effectiveness of inactivated bovine coronavirus vaccines and render calves more susceptible to infectious disease. Therefore, vitamin A could be a promising option for the prevention of lung infection linked to novel coronavirus.

Vitamin C: It is an essential nutrient required by human body mainly due to the fact that they are not synthesized in the human body due to lack of enzyme l-gluono-glactone ${ }^{[27]}$. It was firstidentified in early 1900's in search for a deficient substance responsible or causing scurvy. It is also known as anti-scurvy vitamin due to its potential effectiveness in preventing scurvy. However the effectiveness of vitamin $\mathrm{C}$ is not limited to scurvy prevention but there are several evidence of vitamin having non-scorbutic effects as well ${ }^{[28]}$. Vitamin C contributes conceivably to the immune modulating effects. Its effectiveness is mainly associated to its role as antioxidant due to its ability to donate electrons to unstable reactive oxygen species thereby preventing from detrimental effects of reactive oxygen species which are generated during normal cell metabolism or through exposure to toxin and pollutants ${ }^{[29]}$. In several experimental settings vitamin $C$ has proved to increase the functioning of phagocytes, proliferation of $\mathrm{T}$ lymphocytes and production of interferon and also plays important role in virus replication. Several controlled trials have proved vitamin $\mathrm{C}$ to be effective in improving endothelial functions [30-31], lowering blood pressure [32], decreasing blood glucose level in type 2 diabetes [33], 
decreasing broncho- constrictions ${ }^{[34,35]}$ and prevention from cold ${ }^{[35-38]}$. A number of researchers have suggested that vitamin $\mathrm{C}$ in high doses is directly virucidal ${ }^{[39-42]}$. The effectiveness of vitamin $\mathrm{C}$ has been observed in preventing several respiratory infections such as pneumonia, bronchitis and also common cold. Numerous studies related to role of vitamin $\mathrm{C}$ on common cold has been extensively studies. A significantly lower incidence of common cold was observed in the group supplemented with vitamin $C^{[37,43]}$. Consistent supplementation of vitamin $\mathrm{C}$ has also results reduction in duration and severity of cold ${ }^{[44]}$. Looking at the effectiveness of vitamin c, the anti- oxidative potential of vitamin c could also be exploited probably for the treatment of respiratory symptoms associated with covid-19. Cytokine release is observed in viral infection ${ }^{[45]}$ which in turn results increased oxidative stress via a common and non-specific pathway. Since the prevention and management of could be mitigated by high doses of vitamin $\mathrm{C}$, the approach could probably be beneficial for covid-19 as well ${ }^{[46]}$.

Vitamin D: A powerful immunoregulator with Vitamin D receptors being expressed by the majority of immune cells ${ }^{[47]}$. It plays a vital role in modulating innate and adaptive immune responses [48]. Vitamin $\mathrm{D}$ is acquired through the diet, however the majority of vitamin $\mathrm{D}$ is synthesized endogenously in the skin ${ }^{[49]}$. Once acquired, vitamin D must then be metabolized step-wise in the liver and kidney into its active form $1 \alpha, 25$-dihydroxyvitamin D3 ${ }^{[49]}$. It has been found in many observational studies and found that Vitamin D deficiency to be independently associated with viral acute respiratory infection and have protective effects against acute respiratory infection. Mc. Cartney et al. also reported many incidences of respiratory tract infection due to deficiency of Vitamin D. Dr Franklan associate professor of clinical surgery at Lousiana State university was shocked to find 100\% deficit of Vitamin D in patients suffering from Covid 19. Dr. M.E Yeolekar, former dean director also stated deficiency of Vitamin D more common in patients with Covid 19.

From clinical aspects, the active form of Vitamin D ( $1 \alpha, 25$ dihydroxy vit $\mathrm{D}$,calcitriol) could play a important role thereby modulating the immune response via vitamin $\mathrm{D}$ receptor and be beneficial as a defense against respiratory tract infection ${ }^{[50]}$. Since immune cells have Vitamin D receptors that affect their ligand binding and as such Vitamin D profoundly influences immunity for example it promotes differentiation of monocytes to macrophages and increases their killing capacity, modulate the production of inflammatory cytokines, support antigen presenting cells. Vitamin D metabolites appear to regulate production of specific antimicrobial proteins that directly kill pathogens and thus are likely help reduce infection including in the lungs ${ }^{[10,51]}$.

Current studies done also specify how low calcitriol enhances the antimicrobial effects of macrophages and monocytes which are important effector cells, fighting against pathogens such as mycobacterium tuberculosis. In the gut, the active form of Vitamin D 1,25 dihydroxyvitamin D3 (calcitriol) alters the $\mathrm{T}$ cell response, favouring $\mathrm{T}$ REG cells and inhibiting production of pro inflammatory cytokines [52] And this proinflammatory cytokines are produced predominantly by activated macrophages and are involved in the upregulation of inflammatory reactions. The important proinflammatory cytokines include IL-1 $\beta$, IL-6, and TNF- $\alpha$. Thus it lowers the inflammatory response.
Selenium: It is an important trace element which is known for its role in non-specific immune responses ${ }^{[53]}$ and its deficiency greatly affects immune cell functioning ${ }^{[54]}$. It is very crucial for chemotactic and phagocytic activity and respiratory burst activities ${ }^{[55]}$. Several studies have observed positive impact of selenium supplementation in fighting respiratory infections ${ }^{[56,57]}$. Lie and colleagues conducted an intervention on 75 young children hospitalized with pneumonia and bronchitis caused by respiratory syncytial virus to evaluate the therapeutic potentialities of selenium supplementation on acute respiratory tract infection. The study showed a lowering in the days required for relief of symptoms in the group supplemented with selenium indicating better immune function on selenium supplementation ${ }^{[58]}$. Steinbrenner et al. in their study have demonstrated the anti viral property of selenium. They found that in dietary supplementation to provide adequate or supranutritional selenium could confer health benefits to patients suffering from some viruses disease ${ }^{[57]}$. Other researchers have also demonstrated the anti viral role of selenium ${ }^{[59-61]}$. Considering the previous studies conducted on beneficial effect of selenium supplementation on patients suffering from viral disease as well as the role of selenium in preventing respiratory infections, it could possibly be though as an important nutrient in covid-19 treatment. Recent studies have also proved selenium supplementation to be beneficial for patients suffering from Covid-19. A study by Zhang et al., $2020^{[62]}$ in their study compared the recovery rate of 17 Chinese cities with variable selenium status. The study reported a significant positive correlation of selenium status with recovery rate of patients. A higher recovery rate was notable in city of Enshi which had higher selenium intake in the world with a recovery rate of almost three times the average for rest of the cities in Hubei province including Wuhan.

Zinc: Zinc is one of the trace element essential for functioning of immune system [63] as such growth, development, and maintenance of immune function. It is responsible for various functions as such inflammation and inducing cell mediated immunity and also a key component of pathogen eliminating transduction pathways that contribute to neutrophil extracelluar trap (networks which binds pathogen) formation ${ }^{[64]}$. Therefore zinc deficiency is associated with susceptibility to infectious diseases as such HIV. A review of several studies concluded that zinc supplementation for more than 3 months could be effective in preventing pneumonia in children younger than 5 years of age ${ }^{[65]}$.

Macronutrients: Along with the micronutrients, the macronutrients also play a major role in immunity. There are certain nutritional guidelines given under expert recommendations as nutrition therapy of patients suffering from Covid $19^{\text {[66-67]. }}$

In terms of Energy intake as it is known as Covid 19 patients need more energy than normal patients due to increase in body temperature as $1 \mathrm{deg}$ Celsius rise in body temperature leads to increase in $10 \%$ of body's energy composition. Therefore it is essential to maintain the energy balance in Covid patients since in low debt might lead to complications. For example there might be complications if the patient undergo cumulative energy debt of $33494 \mathrm{KJ}$ and above $41868 \mathrm{KJ}$, the patient may die ${ }^{[68]}$. Protein is recommended 1.3 
$\mathrm{kg} /$ day thereby to increase the supply of branched chain amino acids to prevent $50 \%$ of muscle loss and also to strengthen the respiratory muscle $[69,70]$. Carbohydrate administration to be limited in critically ill Covid patient with respiratory failure and $2 \mathrm{~g} / \mathrm{kg} /$ day and must not exceed $150 \mathrm{~g}$ per day. When a mole of carbohydrates is oxidized then it leads to the production of equal $\mathrm{CO} 2$. And in terms of respiratory failure, production of carbon dioxide must be avoided to decrease the respiratory quotients. In terms of fat, omega 3 and omega-9 fatty acid quotient to be increased in the diet as essential fatty acid plays a major role in immune responses thereby altering the composition of cell membranes and cell signalling. Along with all the nutrients, fluid balance is very essential and to be maintained in Covid 19 patient. For ICU patients, $30 \mathrm{ml} / \mathrm{kg} /$ day for adults and $28 \mathrm{ml} / \mathrm{kg} /$ day for elderly is recommended. For every $1^{\circ} \mathrm{C}$ rise in body temperature, supplement $3-5 \mathrm{~mL} / \mathrm{kg}$ (calculated as $4 \mathrm{~mL} / \mathrm{kg}$ ) [66].

Conclusion: As per the studies done and recommendations provided by the experts, it can be concluded that immunonutrients can play a major role as intervention or prehabilitation to fight against the hazardous symptoms associated with Covid 19 thereby enhancing the immune responses.

\section{References}

1. WHO (World Health Orrganiation). WHO DirectorGeneral's opening remarks at the media briefing on COVID-19, 2020. Retrieved from https://www.who.int/dg/speeches/detail/who-directorgeneral-s-opening-remarks-at-the-media-briefing- oncovid-19-11- march- 2020.

2. WHO (World Health Organization). Director- General's remarks at the media briefing on 2019- nCoV, 2020. Available: https://www.who.int/dg/speeches/detail/whodirector-general-s- remarks- at- the- media- briefing- on2019- ncov- on- 11- february- 2020.

3. Zhou, P.; Yang, X.L.; Wang, X.G. et al. (2020). A pneumonia outbreak associated with a new coronavirus of probable bat origin. Nature, 579:270-273.

4. https://www.worldometers.info/coronavirus/

5. https://mohfw.gov.in

6. Peng KYD, Meng HQ, Guan L, Leng RR, Zhu BY, Wang et al. Clinical characteristics and outcomes of 112 cardiovascular disease patients infected by 2019-nCoV Zhonghua Xin Xue Guan Bing Za Zhi. 2020; 48:E004.

7. Bourke CD, Jones KDJ, Prendergast AJ. Current understanding of innate immune cell dysfunction in childhood undernutrition. Front. Immunol, 2019. doi: 10.3389/fimmu.2019.01728.

8. Wu C, Chen X, Cai Y, Zhou X, Xu S, Huang H et al. Risk factors associated with acute respiratory distress syndrome and death in patients with coronavirus disease 2019 pneumonia in Wuhan. JAMA Intern Med., 2020. doi: 10.1001/jamainternmed.2020.0994.

9. Covinsky M. Katz Supplemental nutrition assistance program - Do not take the food out of patients mouth JAMA Intern Med, 2020. doi: 10.1001/jamainternmed.2019.7151.

10. Gombart AF, Pierre A, Maggini SA. review of micronutrients and the immune System- Working in harmony to reduce the risk of infection. Nutr. 2020; 12:236.
11. Sommer A. Vitamin A deficiency and clinical disease: an historical overview. The J Nutr. 2008; 138(10):18351839.

12. Pino-Lagos K, Guo Y, Brown C, Alexander MP, Elgueta $\mathrm{R}$, Bennett KA et al. A retinoic acid-dependent checkpoint in the development of CD4+ T cell-mediated immunity. J Expt. Med. 2011; 208(9):1767- 1775.

13. Ross AC. Diet in vitamin A research. In: Sun H, Travis GH, editors. Retinoids, Methods and Protocols. Humana Press, Springer; New York, 2010, 295-313.

14. Bhandari N, Bhan MK, Sazawal S. Impact of massive dose of vitamin A given to preschool children with acute diarrhoea on subsequent respiratory and diarrhoeal morbidity. Br. Med. J. 1994; 309:1404-1407.

15. Chen L, Liu YF, Gong M, Jiang W, Fan Z, Qu P et al. Effects of vitamin A, vitamin A plus zinc, and multiple micronutrients on anemia in preschool children in Chongqing, China. Asia Pac. J. Clin. Nutr., 2012, 21(1).

16. Nikawa T, Odahara K, Koizumi H, Kido Y, Teshima S, Rokutan $\mathrm{K}$ et al. Vitamin A prevents the decline in immunoglobulin A and Th2 cytokine levels in small intestinal mucosa of protein-malnourished mice. J Nutr. 1999; 129:934-941.

17. Soye KJ, Trottier C, Di Lenardo TZ, Restori KH, Reichman L, Miller WH et al. In vitro inhibition of mumps virus by retinoids. Virology journal. 2013; 10(1):1-13.

18. Semba RD, Chiphangwi JD, Miotti PG, Dallabetta GA, Hoover DR, Canner JK et al. Maternal vitamin A deficiency and mother-to-child transmission of HIV-1. The Lancet. 1994; 343(8913):1593-1597.

19. Long KZ, García C, Santos JI, Rosado JL, Hertzmark E, DuPont HL et al. Vitamin A supplementation has divergent effects on norovirus infections and clinical symptoms among Mexican children. The Journal of infectious diseases. 2007; 196(7):978-985.

20. Sommer A. Vitamin A deficiency and the global response. In Forum Nutrition, Nature Publishing Group. 2003; 56:33-35.

21. Aibana O, Franke MF, Huang CC, Galea JT, Calderon R, Zhang $\mathrm{Z}$ et al. Impact of Vitamin $\mathrm{A}$ and Carotenoids on the Risk of Tuberculosis Progression. Clin. Infect. Dis. 2017; 65:900-909.

22. Guilleminault L, Williams EJ, Scott HA, Berthon BS, Jensen M, Wood LG. Diet and Asthma: Is it time to adapt our message. Nutrients. 2017; 9:1227.

23. Topic A, Francuski D, Nikolic A, Milosevic K, Jovicic S, Markovic B et al. The role of oxidative stress in the clinical manifestations of childhood asthma. Fetal Pediatr. Pathol. 2017; 36:294-303.

24. Strzelak A, Ratajczak A, Adamiec A, Feleszko W. Tobacco smoke induces and alters immune responses in the lung triggering inflammation, allergy, asthma and other lung diseases: A mechanistic review. Int. J Environ. Res. Public Health. 2018; 15:1033.

25. Jeet J, Hoet AE, Azevedo MP et al. Effects of dietary vitamin A content on anti body responses of feed locales culated intramuscularly with an inactivated bovine coronavirus vaccine. Am J Vet Res. 2013; 74:1353-1362.

26. Burns JJ. Missing step in man, monkey and guinea pig required for the biosynthesis of L-ascorbic acid. Nature. 1957; 180(4585):553-553.

27. Hemilä H. Do vitamins $C$ and E affect Respiratory Infections? Ph.D. Thesis, University of Helsinki, Helsinki, Finland, Available online, 2006. 
https://hdl.handle.net/10138/20335 (accessed on 17 March 2017).

28. Carr AC, Frei B. Toward a new recommended dietary allowance for vitamin $\mathrm{C}$ based on antioxidant and health effects in humans. Am. J lin. Nutr. 1999; 69(6):10861107.

29. Ashor AW, Siervo M, Lara J, Oggioni C, Afshar S, Mathers JC. Effect of vitamin $\mathrm{C}$ and vitamin $\mathrm{E}$ supplementation on endothelial function: a systematic review and meta-analysis of randomised controlled trials. Br. J Nutr. 2015; 113(8):1182-1194.

30. Thosar SS, Bielko SL, Wiggins CS, Klaunig JE, Mather $\mathrm{KJ}$, Wallace JP. Antioxidant vitamin $\mathrm{C}$ prevents decline in endothelial function during sitting. Medical science monitor: international medical journal of experimental and clinical research. 2015;21:1015.

31. Juraschek SP, Guallar E, Appel LJ, Miller ER. Effects of vitamin $C$ supplementation on blood pressure: a metaanalysis of randomized controlled trials. The Am. J.Clin. Nutr. 2012; 95(5):1079-1088.

32. Ashor AW, Werner AD, Lara, J, Willis ND, Mathers JC, Siervo M. Effects of vitamin C supplementation on glycaemic control: a systematic review and meta-analysis of randomized controlled trials. Eu. J lin. Nutr. 2017; 71(12):1371-1380.

33. Hemilä $H$. The effect of vitamin $C$ on bronchoconstriction and respiratory symptoms caused by exercise: a review and statistical analysis. Allergy, Asthma \& Clinical Immunology. 2014; 10(1):1-11.

34. Hemilä $\mathrm{H}$, Chalker E. Vitamin $\mathrm{C}$ for preventing and treating the common cold. Cochrane database of systematic reviews, 2013, (1).

35. Hemilä H, Herman ZS. Vitamin C and the common cold: a retrospective analysis of Chalmers' review. Journal of the American College of Nutrition. 1995; 14(2):116-123.

36. Hemilä H. Vitamin $\mathrm{C}$ and common cold incidence: a review of studies with subjects under heavy physical stress. International journal of sports medicine. 1996; 17(05):379-383.

37. Pauling L. Vitamin $\mathrm{C}$ and the common cold. Canadian Medical Association Journal. 1971; 105(5):448.

38. Pauling L, Rath M. An orthomolecular theory of human health and disease. J Orthomol Med. 1991; 6:135-138.

39. Kim Y, Kim H, Bae S, Choi J, Lim SY, Lee $\mathrm{N}$ et al. Vitamin $C$ is an essential factor on the anti-viral immune responses through the production of interferon- $\alpha / \beta$ at the initial stage of influenza A virus (H3N2) infection. Immune network. 2013; 13(2):70-74.

40. Li W, Maeda N, Beck MA. Vitamin C deficiency increases the lung pathology of influenza Virus-Infected gulo-/- mice. J. Nutr. 2006; 136(10):2611-2616.

41. Cai Y, Li YF, Tang LP, Tsoi B, Chen M, Chen H et al. A new mechanism of vitamin $\mathrm{C}$ effects on $\mathrm{A} / \mathrm{FM} / 1 / 47$ (H1N1) virus-induced pneumonia in restraint-stressed mice. BioMed research international, 2015.

42. Hemilä H. Vitamin $C$ intake and susceptibility to the common cold. British Journal of Nutrition. 1997; 77(1):59-72.

43. Hemilä H. Vitamin $C$ and the common cold. British Journal of nutrition. 1992; 67(1):3-16.

44. Fowler AA, Kim C, Lepler L, Malhotra R, Debesa O, Natarajan $\mathrm{R}$ et al. Intravenous vitamin $\mathrm{C}$ as adjunctive therapy for enterovirus/rhinovirus induced acute respiratory distress syndrome. World Journal of Critical Care Medicine. 2017; 6(1):85.
45. Cheng RZ. Can early and high intravenous dose of vitamin C prevent and treat coronavirus disease 2019 (COVID-19)?. Medicine in Drug Discovery. 2020; 5:100028.

46. Sassi F, Tamone CD, Amello $\mathrm{P}$ et al. Hormone and immunodulator. Nutrients, 2018, 10.

47. Wu JZP. Treatment strategies for reducing damages to lungs in patients with coronavirus and other infections. Preprints, 2020.

48. Jones G, Strugnell SA, Deluca HF. Current understanding of the molecular actions of vitamin D. Physiol. Rev. 1998; 78:1193-1231.

49. Provvedini DM, Tsoukas CD, Deftos LJ, Manolagas SC. 1,25-Dihydroxyvitamin $\mathrm{D}_{3}$ receptors in human leukocytes science. 1983; 229:1811-1183.

50. Greiler C, Martineau A. Modulation of the immune response to respiratory viruses by Vitamin D. Nutrients. 2015; 7:4240-4270.

51. Jeffery LE, Burke F, Mura M, Zheng Y, Qureshi OS, Walker LSK et al. 1,25-dihydroxyvitamin D3 and interleukin-2 combine to inhibit $\mathrm{T}$ cell production of inflammatory cytokines and promote development of regulatory $\mathrm{T}$ cells expressing CTLA-4 and FoxP3. J. Immunol. 2009; 183:5458-5467.

52. Dercksen DP, Counotte GH, Hazebroek MK, Arts W, Van RT. Selenium requirements of dairy goats. Tijdschr. Diergeneeskd. 2007; 132:468-471.

53. Effraimidis G, Wiersinga WM. Mechanisms in endocrinology: autoimmune thyroid disease: old and new players. European journal of endocrinology. 2014; 170(6):41- 52.

54. Radostits OM, Gay CC, Hinchcliff KW, Constable PD. Veterinary Medicine: A textbook of the diseases of cattle, sheep, goats, pigs and horses, 10th edn, Saunders Elsevier, Edinburgh, 2007.

55. Beck MA, Nelson HK, Shi Q, Van Dael P, Schiffrin EJ, Blum $S$ et al. Selenium deficiency increases the pathology of an influenza virus infection. The FASEB Journal. 2001; 15(8):1481-1483.

56. Steinbrenner H, Al-Quraishy S, Dkhil MA, Wunderlich F, Sies H. Dietary selenium in adjuvant therapy of viral and bacterial infections. Adv. Nutr. 2015; 6(1):73-82.

57. Liu X, Yin S, Li G. Effects of selenium supplement on acute lower respiratory tract infection caused by respiratory syncytial virus. Chinese Journal of Preventive Medicine. 1997; 31(6):358-361.

58. Luty-Frackiewiz ANNA. The role of selenium in cancer and viral infection prevention. Int. J Occup. Med. Environ. Health. 2005; 18(4):305-311.

59. Guillin OM, Vindry C, Ohlmann T, Chavatte L. Selenium, selenoproteins and viral infection. Nutr. 2019; 11(9):2101.

60. Gill H, Walker G. Selenium, immune function and resistance to viral infections. Nutr. Diet. 2008; 65:S41S47.

61. Zhang J, Taylor EW, Bennett K, Saad R, Rayman MP. Association between regional selenium status and reported outcome of COVID-19 cases in China. The Am. J Clin. Nutr. 2020; 111(6):1297-1299.

62. Wessels I, Maywald M, Rink L et al. Zinc as a gatekeeper of immune function. Nutr. 2017; 9:1286.

63. Gammoh NZ, Rink L. Zinc in infection and inflammation. Nutrients. 2017; 9:E624. 
64. Sakulchit T, Goldman RD. Zinc supplementation for pediatric pneumonia. Can. Fam. Physician. 2017; 63:763-765.

65. Kaiying Y, Hanping S. Interpretation of expert recommendations on medical nutrition therapy for patients with new Coronavirus pneumonia. Nat. Med. J China. 2020; 100:724-728.

66. Singer P, Blaser AR, Berger MM, AlHazzani W, Calde RPC, CaSaeR MP et al. ESPEN guideline on clinical nutrition in the intensive care unit. Clin. Nutr. 2019; 38:48-79.

67. MCClave Sa, tayloR be, MaRtindale Rg, WaRRen MM, JoHnSon dR, bRaunSCHWeig C et al. Society of Critical Care Medicine, American Society for Parenteral and Enteral Nutrition. Guidelines for the provision and assessment of nutrition support therapy in the adult critically ill patient: Society of Critical Care Medicine (SCCM) and American Society for Parenteral and Enteral Nutrition (A.S.P.E.N.). J Parenter. Enteral Nutr. 2016; 40:159-211.

68. Villet S, Chiolero R, Bollmann MD, Revelly JP, Cayeux RMC, Delarue J et al. Negative impact of hypocaloric feeding and energy balance on clinical outcome in ICU patients. Clin. Nutr. 2005; 24:502-509.

69. Cholewa JM, daRdeve D, Lima-soares F, de Araújo pessôa K, Oliveira $\mathrm{PH}, \operatorname{doS}$ SantospinHo JR et al. Dietary proteins and amino acids in the control of the muscle mass during immobilization and aging: role of the MPS response. Amino Acids. 2017; 49:811-820

70. Tappy L, Schwarz JM, Schneiter P, Cayeux C, Revelly JP, Fagerquist CK et al. Effects of isoenergetic glucosebased or lipid-based parenteral nutrition on glucose metabolism, de novo lipogenesis, and respiratory gas exchanges in critically ill patients. Crit. Care Med. 1998; 26:860-867. 